\title{
TOLNet - A Tropospheric Ozone Lidar Profiling Network for Satellite Continuity and Process Studies
}

\author{
Michael J. Newchurch ${ }^{1^{*}}$, Shi Kuang ${ }^{1}$, Thierry Leblanc ${ }^{2}$, Raul J. Alvarez $\mathbf{I I}^{3}$, Andrew O. Langford ${ }^{3}$, \\ Christoph J. Senff ${ }^{3,4}$, John, F. Burris ${ }^{5}$, Thomas J. McGee, John T. Sullivan ${ }^{5,6}$, Russell J. DeYoung ${ }^{7}$, \\ Jassim Al-Saadi ${ }^{7}$, Matthew Johnson ${ }^{8}$, Alex Pszenny ${ }^{9}$ \\ ${ }^{1}$ Atmospheric Science Department, University of Alabama in Huntsville, Huntsville, AL 35805, USA \\ ${ }^{2}$ NASA Jet Propulsion Laboratory, Wrightwood, CA 92397, USA \\ ${ }^{3}$ NOAA Earth System Research Laboratory, Boulder, CO 80305, USA \\ ${ }^{4}$ Cooperative Institute for Research in the Environmental Sciences, University of Colorado at Boulder, \\ Boulder, CO 80309, USA \\ ${ }^{5}$ NASA Goddard Space Flight Center, Greenbelt, MD 20771, USA \\ ${ }^{6}$ Dept. of Atmospheric Physics, University of Maryland Baltimore County, Baltimore, MD 21250, USA \\ ${ }^{7}$ NASA Langley Research Center, Hampton, VA 23681, USA \\ ${ }^{8}$ NASA Ames Research Center, Moffett Field, CA 94031, USA \\ ${ }^{9}$ NASA Headquarters, Washington, DC 20546, USA \\ *Corresponding author: mike@nsstc.uah.edu
}

\begin{abstract}
Ozone lidars measure continuous, highresolution ozone profiles critical for process studies and for satellite validation in the lower troposphere. However, the effectiveness of lidar validation by using single-station data is limited. Recently, NASA initiated an interagency ozone lidar observation network under the name TOLNet to promote cooperative multiple-station ozone-lidar observations to provide highly timeresolved (few minutes) tropospheric-ozone vertical profiles useful for air-quality studies, model evaluation, and satellite validation. This article briefly describes the concept, stations, major specifications of the TOLNet instruments, and data archiving.
\end{abstract}

\section{Background}

Although the U.S. EPA (Environmental Protection Agency) reports hourly surface ozone mixing ratios from a dense national ground-level monitoring network, upper-air ozone observations are extremely sparse. Ozone can be generated throughout the troposphere as a secondary product of industrial or mobile emissions and it can also be transported from the stratosphere [1]. Upper-air observations are particularly important because the ozone produced aloft and transported over appreciable distances can significantly affect surface air quality.

Lidar offers a number of significant advantages including continuous high spatial and temporal resolution vertical profiles, automated, high-quality retrievals under both day and nighttime conditions, and the ability to generate consistent, long-term, data sets. The lidar observations are critically important when a requirement exists for continuous ozone retrievals with high temporal and vertical resolution such as in the PBL where chemical and physical variations are both rapid and complicated. Ground-based lidars, including mobile and fixed-station configurations, have lower operation cost than airborne lidars but have limited geographic coverage. This limitation motivates the development of a ground-based ozone lidar network to make simultaneous ozone profiling at multiple locations for process studies, model evaluation and satellite validation at reasonable cost.

TOLNet, the Tropospheric Ozone Lidar Network, is an interagency initiative started by NASA, NOAA, and USEPA in 2011 to provide highly time resolved measurements of 
tropospheric ozone vertical profiles to address fundamental air-quality science questions in cooperation with national, state, and local organizations. TOLNet also contributes to intensive field campaigns such as DISCOVER$\mathrm{AQ}$, and development of future satellite missions GEOstationary Coastal and Air Pollution Events (GEO-CAPE), and Tropospheric Emissions: Monitoring of Pollution (TEMPO).

\section{Objectives and Recent Activity}

The primary scientific objective of TOLNet is to provide high spatio-temporal measurements of ozone from near surface to the top of the troposphere. Such high-fidelity lidar measurements can provide accurate representations of the PBL and free-tropospheric ozone structure. With these observations of the detailed ozone structure, satellite science teams and the modeling community can study the character of lower-atmospheric ozone and also assess the accuracy and vertical resolution with which a geosynchronous instrument could retrieve the observed laminar ozone structures.

A second objective is to identify an ozone lidar instrument design that would be suitable to populate an expanded network to address the needs of NASA/EPA/NOAA airquality scientists and managers who increasingly express a desire for ozone vertical profiles.

The third motivation for TOLNet is basic scientific research into the processes creating and destroying the ubiquitously observed ozone laminae and other ozone features in the troposphere. The sources and mechanisms controlling ozone distribution and variations are being investigated by using highresolution lidar data, synergistic meteorological measurements, and atmospheric chemistry model simulations.

TOLNet recently contributed simultaneous observations of ozone profiles to the summer 2014 DISCOVER-AQ Colorado campaign with all three lidars first deployed together at the NOAA Boulder Atmospheric Observatory (BAO), and then separately at Ft. Collins, Golden, and the BAO. The individual lidars have also conducted measurements at various sites from California to Maryland. The scientific foci of these observations include the following: Los Angeles pollution outflow; stratosphere-troposphere exchange (STE) and transport from East Asia; wintertime ozone exceedances resulting from oil and gas development in Utah; Southeast US ozone structure and variability resulting from lightning, STE, laminar evolution, and residual layer transport and entrainment; Chesapeake Bay effects on PBL ozone; and correlative measurement with the NSF-sponsored Wintertime Investigation of Transport, Emission, and Reactivity (WINTER) campaign in early 2015.

\section{Stations and Instruments}

TOLNet currently comprises five lidars, including three mobile systems located at the NOAA Earth System Research Laboratory (ESRL, Boulder, CO), NASA Langley Research Center (LaRC, Hampton, VA), and NASA Goddard Space Flight Center (GSFC, Greenbelt, MD), and two fixed-base systems located at the NASA Jet Propulsion Laboratory, Table Mountain, CA), and the University of Alabama in Huntsville (UAH, Huntsville, AL). Some of these lidar stations already had a long observation history before becoming part of the TOLNet.

Table 1 summarizes the major specifications of the TOLNet lidars. Currently, Nd:YAG pumped Raman-shifted lasers at 289 and $299 \mathrm{~nm}$ are popular for ozone measurement due to their easy installation, robustness, good conversion efficiency, and good output beam quality [2]. However, the Nd:YLF pumped Ce:LiCAF laser offer flexibility on wavelength choice. Near-surface ozone retrieval has been difficult for ozone lidars due to the required altitude for overlap between laser beam and telescope caused by the bistatic configuration. Recently, some TOLNet stations have extended the ozone lidar observations down to $125 \mathrm{~m}$ AGL by modifying the lidar receiving system [3] to better characterize the interactions between surface and upper air.

\section{Lidar data QA/QC and archiving}

The uncertainty of the ozone lidar retrievals depends strongly on the signal 
integration time and the vertical (or spatial) resolution. The TOLNet lidars generally retrieve ozone at an uncertainty of $\sim 10 \%$ at near-range and $\sim 20 \%$ at far range with an integration time of few minutes and vertical resolution of hundreds of meters $[4,6,7,8]$. Most of the TOLNet lidars validate their ozone retrievals using collocated ozonesonde measurements although occasional intercomparison between TOLNet lidars was made (e.g., during the summer 2014 DISCOVER-AQ Boulder campaign). Standardization of the retrieval algorithm and definition of the vertical resolution for all TOLNet lidars is an ongoing project.

The TOLNet data are accessible at consulting with the instrument principal or coinvestigators before usage is highly encouraged. We provide the digital data to users with both the widely used ICARTT format(http://wwwir.larc.nasa.gov/missions/etc/

IcarttDataFormat.htm) and the TOLNet format which is a new data protocol recently formed by the TOLNet working group. Figure 1 shows the TOLNet data webpage and few lidar curtain examples.

\section{Summary}

NASA's TOLNet has made significant progress toward enhancing the capability for vertical ozone profiling and fostering corporation between five member stations including NASA/JPL, NOAA/ESRL, UAH, NASA/GSFC, and NASA/LaRC. All these stations have made considerable progress concerning lidar platform construction, receiver or transmitter upgrades, and near-surface channel development since the initiation of this project. A vehicle for the public archiving and dissemination of TOLNet data using two well-defined standards has been developed to promote research and collaboration among TOLNet investigators and the broader scientific community. A main objective of TOLNet is to provide high-resolution lidar data at multiple stations to modeling and satellite teams for validating and improving the fidelity of tropospheric ozone measurements by NASA's next-generation geostationary instruments.

\section{References}

[1] Kuang, S., M. J. Newchurch, J. Burris, L. Wang, K. Knupp, G. Huang, 2012: Stratosphere-to-troposphere transport revealed by ground-based lidar and ozonesonde at a midlatitude site, J. Geophys. Res., 117, D18305.

[2] Schoulepnikoff, L. de, V. Mitev, V. Simeonov, B. Calpini, H. van den Bergh, 1997: Experimental investigation of high-power single-pass Raman shifters in the ultraviolet with Nd:YAG and KrF lasers, Appl. Opt., 36, 50265043.

[3] Kuang, S., M. J. Newchurch, J. Burris, X. Liu, 2013: Ground-based lidar for atmospheric boundary layer ozone measurements, Appl. Opt., 52, 3557-3566.

[4] McDermid, I., G. Beyerle, D. Haner, T. Leblanc, 2002: Redesign and improved performance of the tropospheric ozone lidar at the jet propulsion laboratory table mountain facility, Appl. Opt., 41, 7550-7555.

[5] Alvarez, R. J., et al, 2011: Development and application of a compact, tunable, solid-state airborne ozone lidar system for boundary layer profiling, J. Atmos. Ocean. Technol., 28, 12581271.

[6] Kuang, S., J. F. Burris, M. J. Newchurch, S. Johnson, S. Long, 2011: Differential Absorption Lidar to measure subhourly variation of tropospheric ozone profiles, IEEE Trans. Geosci. Remote Sens., 49, 557-571.

[7] Sullivan, J. T., $\quad$ McGee, T. J., Sumnicht, G. K., Twigg, L. W., and Hoff, R. M., 2014: A mobile differential absorption lidar to measure sub-hourly fluctuation of tropospheric ozone profiles in the Baltimore-Washington, D.C. region, Atmos. Meas. Tech., 7, 3529-3548.

[8] De Young, R.J., Carrion, W., Pliutau, D.: A Compact Mobile Ozone Lidar for Atmospheric Ozone and Aerosol Profiling, Proceedings of SPIE Remote Sensing Conf., 9246-7, Amsterdam, Netherlands, September 2014. 
Table 1. Summary of the TOLNet lidars.

\begin{tabular}{|c|c|c|c|c|c|}
\hline Name & $\begin{array}{l}\text { JPL TMO } \\
\text { (Table } \\
\text { Mountain } \\
\text { tropospheric } \\
\text { Ozone) DIAL }\end{array}$ & $\begin{array}{l}\text { TOPAZ } \\
\text { (Tunable } \\
\text { Optical } \\
\text { Profiler for } \\
\text { Aerosol and } \\
\text { oZone) lidar }\end{array}$ & $\begin{array}{l}\mathrm{RO}_{3} \mathrm{QET} \\
\text { (Rocket-city O3 } \\
\text { Quality } \\
\text { Evaluation in } \\
\text { theTroposphere) } \\
\text { lidar }\end{array}$ & $\begin{array}{l}\text { GSFC } \\
\text { TROPOZ } \\
\text { (TROPospheric } \\
\text { OZone) DIAL }\end{array}$ & $\begin{array}{l}\text { LMOL } \\
\text { (Langley } \\
\text { Mobile Ozone } \\
\text { Lidar) }\end{array}$ \\
\hline Affiliation & NASA/JPL & NOAA/ESRL & UAH & NASA/GSFC & NASA/LaRC \\
\hline Host location & $\begin{array}{l}\text { Wrightwood, } \\
\text { CA }\end{array}$ & Boulder, CO & Huntsville, AL & Greenbelt, MD & Hampton, VA \\
\hline Set-up & Fixed-location & Mobile & Fixed-location & Mobile & Mobile \\
\hline $\begin{array}{l}\text { Transmitter } \\
\text { type }\end{array}$ & $\begin{array}{l}\text { Quadruple } \\
\text { Nd:YAG } \\
\text { pumped } \\
\text { Raman laser }\end{array}$ & $\begin{array}{l}\text { Quadruple } \\
\text { Nd:YLF } \\
\text { pumped } \\
\text { Ce:LiCAF } \\
\text { laser (tunable } \\
\text { wavelength) }\end{array}$ & $\begin{array}{l}\text { Quadruple } \\
\text { Nd:YAG } \\
\text { pumped Raman } \\
\text { laser }\end{array}$ & $\begin{array}{l}\text { Quadruple } \\
\text { Nd:YAG } \\
\text { pumped } \\
\text { Raman laser }\end{array}$ & $\begin{array}{l}\text { Quadruple } \\
\text { Nd:YLF } \\
\text { pumped } \\
\text { Ce:LiCAF } \\
\text { laser (tunable } \\
\text { wavelength) }\end{array}$ \\
\hline $\begin{array}{l}\text { Wavelength } \\
(\mathrm{nm})\end{array}$ & 289,299 & $\begin{array}{l}\text { Typically } 287, \\
291,294\end{array}$ & $283,289,299$ & 289,299 & $\begin{array}{l}\text { Typically } 285 \text {, } \\
291 \text { ( } 527 \text { for } \\
\text { aerosol) }\end{array}$ \\
\hline $\begin{array}{l}\text { Receiver size } \\
\text { (cm) }\end{array}$ & $91,5,5$ & 50 & $40,10,2.5$ & $41,2.5,2.5$ & 40 \\
\hline $\begin{array}{l}\text { Measurable } \\
\text { range }(\mathbf{k m} \\
\text { AGL) }\end{array}$ & $0.1-23$ & $0-3$ & $0.1-12$ & $\begin{array}{l}0.2-12 \text { (day) } \\
0.2-19 \text { (night) }\end{array}$ & $0.1-4$ \\
\hline Reference & [4] & [5] & {$[3,6]$} & [7] & [8] \\
\hline
\end{tabular}

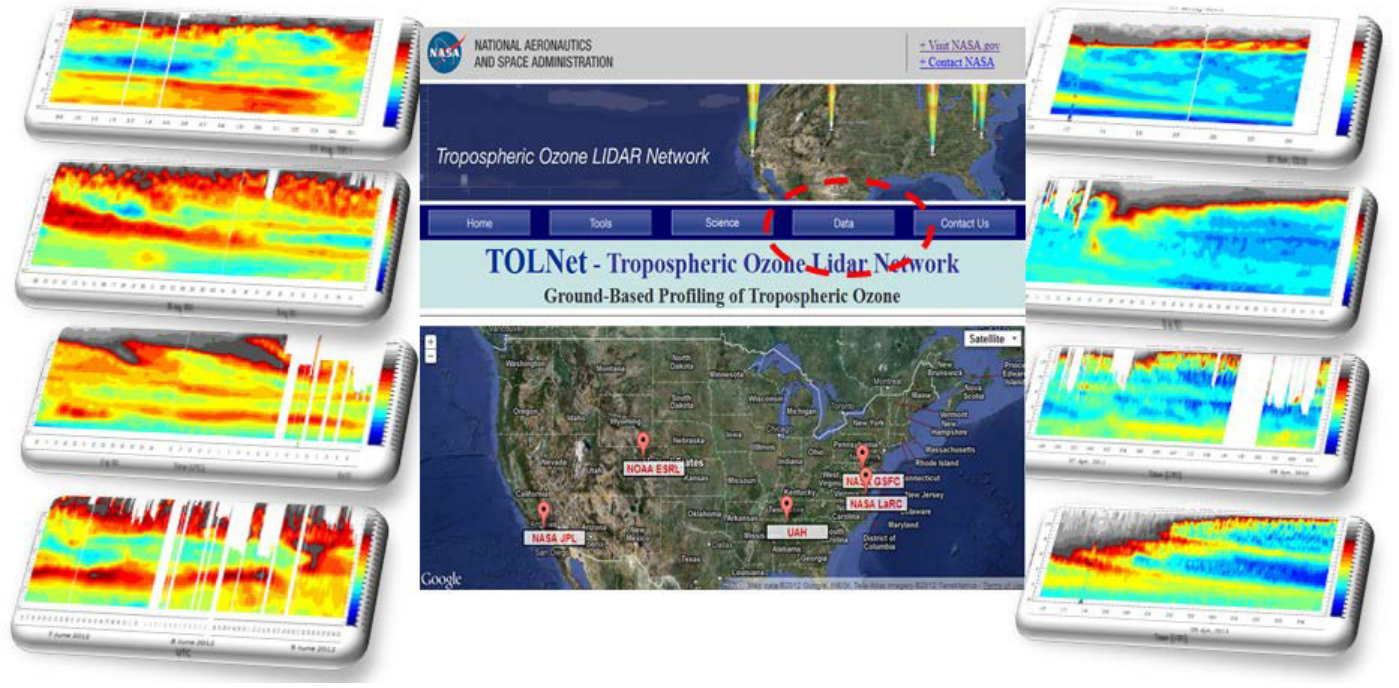

Figure 1. TOLNet webpage and lidar measurement examples. Left ozone curtains are measured in summer and the right curtains are measured in spring/fall. 